\title{
Connexin mutants and cataracts
}

\author{
Eric C. Beyer ${ }^{1}$ *, Lisa Ebihara' ${ }^{2}$ and Viviana M. Berthoud ${ }^{1}$ \\ 1 Department of Pediatrics, University of Chicago, Chicago, IL, USA \\ ${ }^{2}$ Department of Physiology and Biophysics, Rosalind Franklin Health Sciences University, North Chicago, IL, USA
}

\section{Edited by:}

Stefan Dhein, Universitätsklinik

Leipzig Herzzentrum Leipzig GmbH,

Germany

\section{Reviewed by:}

Luc Leybaert, Ghent University, Belgium

Richard Warth, University of

Regensburg, Germany

\section{${ }^{*}$ Correspondence:}

Eric C. Beyer, Department of

Pediatrics, University of Chicago, 900

East 57th Street, KCBD 5152,

Chicago, IL 60637, USA.

e-mail: ecbeyer@uchicago.edu
The lens is a multicellular, but avascular tissue that must stay transparent to allow normal transmission of light and focusing of it on the retina. Damage to lens cells and/or proteins can cause cataracts, opacities that disrupt these processes. The normal survival of the lens is facilitated by an extensive network of gap junctions formed predominantly of connexin46 and connexin50. Mutations of the genes that encode these connexins (GJA3 and GJA8) have been identified and linked to inheritance of cataracts in human families and mouse lines. In vitro expression studies of several of these mutants have shown that they exhibit abnormalities that may lead to disease. Many of the mutants reduce or modify intercellular communication due to channel alterations (including loss of function or altered gating) or due to impaired cellular trafficking which reduces the number of gap junction channels within the plasma membrane. However, the abnormalities detected in studies of other mutants suggest that they cause cataracts through other mechanisms including gain of hemichannel function (leading to cell injury and death) and formation of cytoplasmic accumulations (that may act as light scattering particles). These observations and the anticipated results of ongoing studies should elucidate the mechanisms of cataract development due to mutations of lens connexins and abnormalities of other lens proteins. They may also contribute to our understanding of the mechanisms of disease due to connexin mutations in other tissues.

Keywords: connexin46, connexin50, cataract, lens, gap junction

\section{THE LENS AND CATARACTS}

The lens is a transparent organ whose main function is to transmit light and focus it on the retina. It sits suspended between two clear fluids (the aqueous humor and the vitreous) and has no direct blood supply (Figure 1A). The lens is comprised of two cell types: epithelial cells that form a single layer along the anterior surface and fiber cells that form the bulk of the organ (Figure 1B). At the lens equator, epithelial cells differentiate into fiber cells, a process that involves cell elongation and loss of nuclei and organelles. This differentiation process occurs throughout the lifespan of the organism. Lens fiber cells contain very high concentrations of small soluble proteins called crystallins. These proteins act as chaperones and increase the refractive index (but do not interfere with transparency). Mature fiber cells have limited metabolic activities, are non-dividing, and must survive for the lifespan of the organism. Most of the metabolic, synthetic, and active transport machinery in the lens is localized to surface (nucleated) cells (Mathias and Rae, 2004).

A cataract is a cloudiness or opacity in the lens. It may cause a decrease in vision and may eventually lead to blindness. This disease has substantial public health consequences, because cataracts are the leading cause of blindness worldwide (Resnikoff et al., 2004). Even in those countries where cataractous lenses are surgically removed and replaced with prosthetic intraocular lenses, this eye pathology has a major financial impact. Therefore, many efforts have been devoted to determine the factors that lead to cataract formation and to develop treatments to prevent their formation. Cataracts can be subdivided according to their anatomical location within the lens (e.g., cortical, nuclear, sub-capsular), their appearance (e.g., total, pulverulent), and most commonly by a combination of these two parameters (e.g., nuclear pulverulent). They can also be subdivided according to their etiology (e.g., congenital, disease-related, or age-related). The specific biochemical and structural changes associated with cataract formation are diverse, but a common biochemical change is the presence of high molecular weight insoluble protein aggregates (Moreau and King, 2012).

Because the lens does not have a direct blood supply, the nutrients for the organ all derive from the fluids in which it is suspended. Specifically, the aqueous humor (which is dynamically produced from the plasma and subsequently resorbed) provides the main source for inorganic and organic ions, carbohydrates, glutathione, amino acids, and oxygen. The aqueous humor is also the repository for metabolites and carbon dioxide produced by lens cells. Ions and nutrients reach cells in the interior through an internal "circulation" in which flow of ions and water drives the movement of solutes throughout the organ. A model of this circulation has been developed based on surface currents recorded from lenses (Robinson and Patterson, 1982; Parmelee, 1986; Mathias et al., 1997) and measurements of hydrostatic pressures at different depths within the lens (Gao et al., 2011). In this model, current carried by ions (and associated water and solutes) enters the lens along the extracellular spaces at the anterior and posterior poles, it crosses fiber cell membranes in the lens interior, and it flows back to the surface 


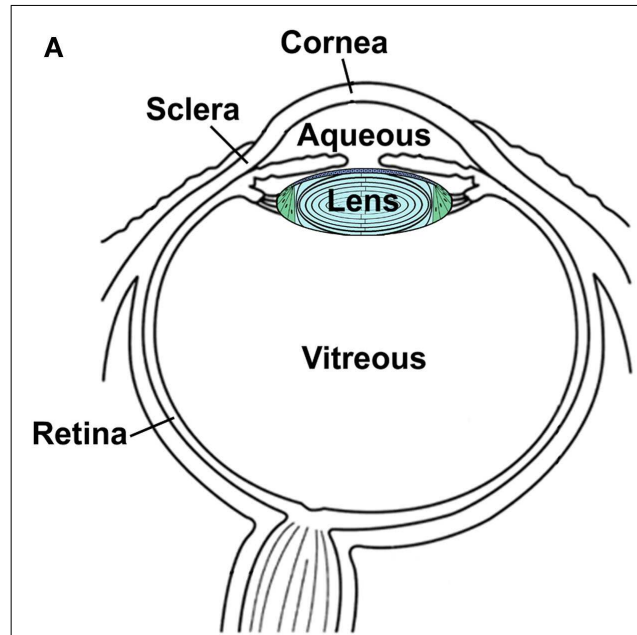

FIGURE 1 |Anatomy of the eye (A) and structure of the lens (B). (A) Diagram of the eye illustrating the location of the lens in relation to other structures. The lens is suspended between two transparent fluids, the aqueous and vitreous humors. The aqueous humor fills the space between the cornea and the lens (as well as the posterior chamber). It contains water, oxygen, carbon dioxide, inorganic and organic ions, carbohydrates, glutathione, urea, amino acids, and proteins (including immunoglobulins and growth factors) and is very dynamic (with turnover rates of $1-1.5 \%$ per minute) (reviewed by Goel et al., 2010). The aqueous humor stabilizes the ocular structure and contributes to the homeostasis of the avascular
B

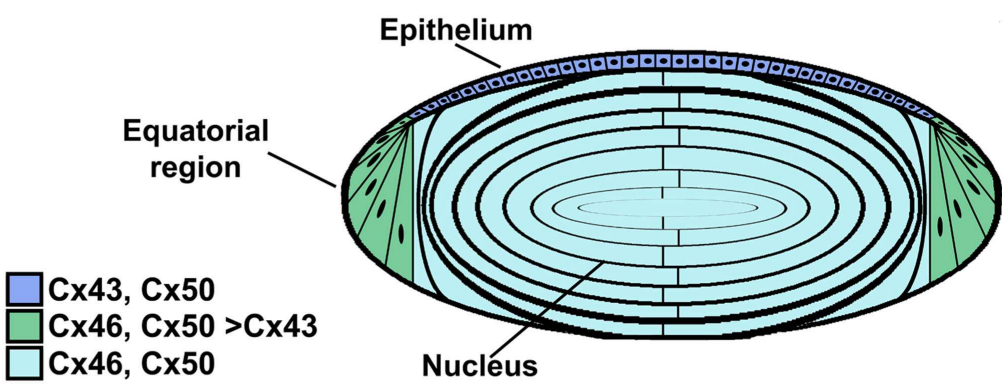

at the equator (through a cell-to-cell pathway) (Mathias et al., 2007, 2010). The hydrostatic pressure gradient also drives water flow toward the exterior (Gao et al., 2011). The lens circulatory system provides a pathway for internal fiber cells to obtain essential nutrients, remove potentially toxic metabolites, and maintain resting potentials (Goodenough, 1979; Piatigorsky, 1980). Thus, fiber cell survival and the maintenance of transparency depend on the function of epithelial cells and on communication between lens cells (Goodenough, 1992).

\section{LENS GAP JUNCTIONS AND CONNEXINS}

Intercellular communication among the cells of the lens is facilitated by an extensive network of gap junctions. Gap junctions are membrane specializations that contain clusters of intercellular channels that are permeable to ions and small solutes $(\leq 1 \mathrm{kDa})$. Lens fiber cells share ions and small metabolites through gap junction channels, and consequently behave as a functional syncytium (Goodenough et al., 1980; Mathias and Rae, 1989). Epithelial and fiber cells contain morphologically and physiologically distinct gap junctions (Rae and Kuszak, 1983; Miller and Goodenough, 1986).

Gap junction channels are oligomeric assemblies of members of a family of related proteins called connexins (Cx) (Beyer and Berthoud, 2009). Connexins contain four transmembrane domains connected by two extracellular loops and one cytoplasmic loop. The amino and carboxyl termini of the polypeptide are in the cytoplasm. Six connexins oligomerize to form a connexin hemichannel which traffics to the plasma membrane of one cell where it can dock with another hemichannel from an adjacent cell to form a complete gap junction channel (Figure 2). Channels formed by diverse connexins differ in physiological properties structures of the anterior part of the eye by providing nutrition and removing metabolic products. The vitreous is a viscous, gelatinous liquid that fills the space between the lens and the retina. It is essentially a specialized extracellular fluid containing collagen fibers, hyaluronic acid and other soluble proteins, and glycoproteins. The vitreous is rather stagnant, equilibrating very slowly with the plasma. (B) Diagram of the lens showing the distribution of connexin isoforms. Cells from the anterior epithelial cell layer express $\mathrm{C} \times 43$ and $\mathrm{C} \times 50$, differentiating fiber cells express $\mathrm{C} \times 43$, $\mathrm{C} \times 46$, and $\mathrm{C} \times 50$, and fiber cells (including those of the nucleus) contain $\mathrm{C} \times 46$ and $\mathrm{C} \times 50$. including unitary conductance, permeability, gating, and regulation by different protein kinase-dependent pathways (reviewed in Harris, 2001, 2007; Saez et al., 2003). Thus, the regulation of intercellular communication and the permeation of different molecules in different regions of the lens are determined by the repertoire of connexins expressed.

Three connexins have been identified in the lens with somewhat overlapping expression patterns (Figure 1B). Cx43 is expressed in lens epithelial cells (Musil et al., 1990), but its expression is turned off as epithelial cells in the equatorial region differentiate into fiber cells. Cx50 is also expressed in epithelial cells (TenBroek et al., 1994; Dahm et al., 1999; Rong et al., 2002). Cx46 and Cx50 become abundantly expressed in the differentiating cells and are the two most abundant connexins in lens fiber cells (Paul et al., 1991; White et al., 1992). Cx46 and Cx50 co-localize at gap junction plaques and can form mixed hexamers (Paul et al., 1991; Jiang and Goodenough, 1996). (Heteromeric mixing is illustrated schematically in Figure 2).

Transcripts for a fourth connexin, Cx23, have been detected in the zebrafish embryo lens (Iovine et al., 2008) and in the mouse lens (Puk et al., 2008). Cx23 has been implicated in fiber cell differentiation, because fiber cells in mice expressing a missense mutation of Cx23 did not appear to elongate properly (Puk et al., 2008). Lens cells from other mammalian species may also express $\mathrm{Cx} 23$, since it has been identified as an expressed sequence in mRNA from whole eyes or lenses ${ }^{1}$. However, Cx23 transcript

\footnotetext{
${ }^{1}$ Accession numbers for Oryctogalus cuniculus EST from eye: EB384661.1, EB384662.1; Bos taurus EST from lens: EG705869.1; Macaca mulatta EST from lens: EG703836.
} 


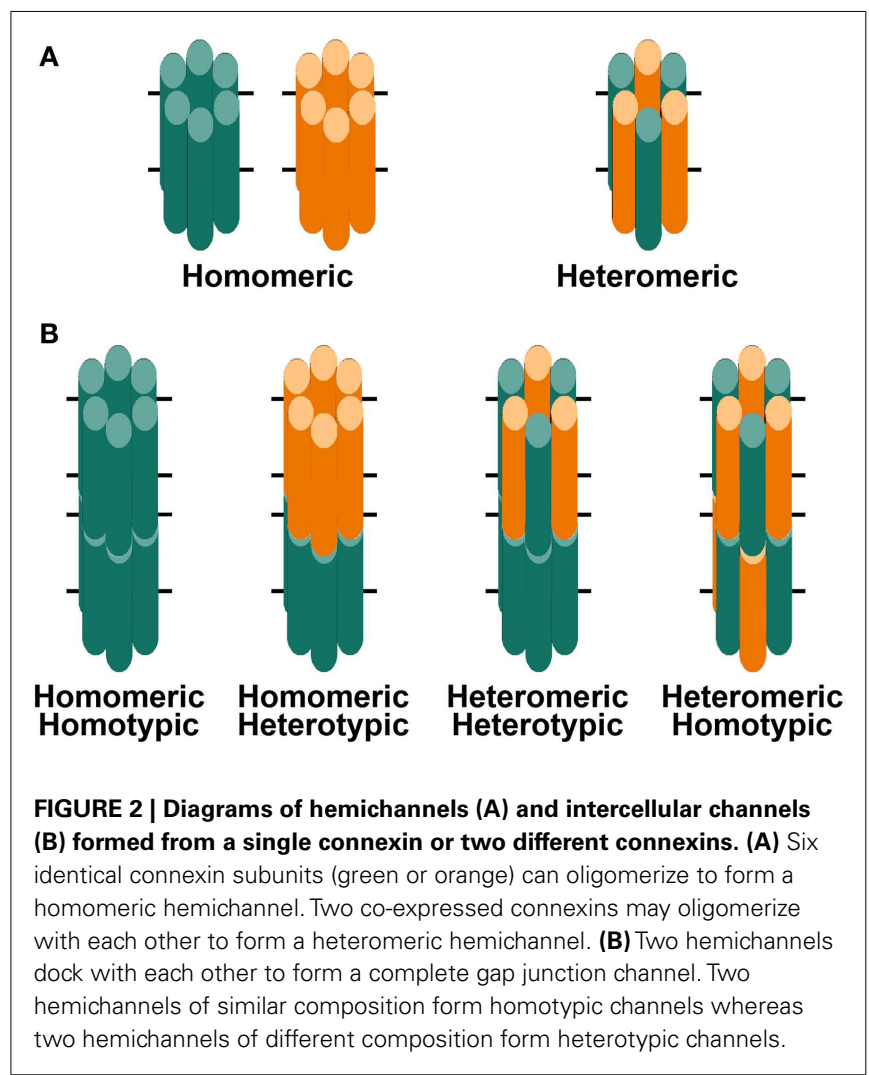

was not detected in RNA isolated from human lenses (Sonntag et al., 2009). Moreover, while Cx23 protein has been detected in proteomic studies of mouse lens membrane proteins (Bassnett et al., 2009), it was not detected in human samples (Wang et al., 2013). Therefore, Cx23 is not included in Figure 1B nor considered further in this review.

\section{MOUSE STUDIES IMPLICATE CONNEXINS IN CATARACTOGENESIS}

The importance of gap junction-mediated lens intercellular communication for the maintenance of lens transparency has been substantiated by a number of genetic studies in mice. Targeted deletion of either $\mathrm{Cx} 46$ or Cx50 results in the development of cataracts in homozygous (but not heterozygous) null mice (Gong et al., 1997; White et al., 1998). The Cx50-null mice have a milder cataract than the Cx46-null mice (Gerido et al., 2003), but Cx50null mice exhibit microphthalmia and smaller lenses (Gong et al., 1997; White et al., 1998; Rong et al., 2002). The onset of the cataract phenotype in Cx50 knock-out mice occurs within the first postnatal week (White et al., 1998; Rong et al., 2002) whereas the cataracts in Cx46-null mice are visible by the third week of age (Gong et al., 1997). The solubility of some crystallins is decreased in both Cx50- and Cx46-null mice. Double knock-out mice lacking both the $\mathrm{Cx} 46$ and $\mathrm{Cx} 50$ genes show dense lens opacities that are far more extensive than those observed in either the $\mathrm{Cx} 46$ or Cx50 single null mice (Xia et al., 2006).

Transgenic mice over-expressing Cx50 also develop severe cataracts (Chung et al., 2007). This finding suggests that any significant alteration of connexin levels in these cells (either absence or a major increase) may lead to cataract formation.

The role of $\mathrm{Cx} 43$ in normal lens function is uncertain. Lenses of prenatal or newborn Cx43-null mice appear normal and transparent ((White et al., 2001) and Berthoud and Beyer, unpublished observations), but Gao and Spray (1998) have observed ultrastructural abnormalities in these lenses. The long-term effects of the loss of $\mathrm{Cx} 43$ in the lens cannot be determined in these mice, because global deletion of $\mathrm{Cx} 43$ results in neonatal lethality (Reaume et al., 1995). However, the lenses of animals with a conditional deletion of Cx43 are transparent and develop normally through at least 6 months of age, even though intercellular transfer of neurobiotin and Lucifer yellow among epithelial cells is decreased (DeRosa et al., 2009).

The cataract trait in several mutant mouse strains has been mapped to the lens connexin loci. The No2 mouse carries a missense mutation within the coding region of $\mathrm{Cx} 50$ resulting in a change of amino acid residue 47 from aspartate to alanine (Cx50D47A) and develops congenital cataracts (Favor, 1983; Steele et al., 1998); these cataracts are less severe in heterozygous than in homozygous animals. Mice carrying a Cx50 mutation at amino acid residue 64 (changing from valine to alanine, Cx50V64A) exhibit dominantly inherited cataracts (Graw et al., 2001). Another mouse with cataracts, lop 10, carries a missense mutation at amino acid residue 22 of Cx50 (Cx50G22R) (Chang et al., 2002). Both cataracts and microphthalmia have been observed in mice with the semi-dominant mutation, Cx50R205G (Xia et al., 2012).

\section{CONNEXIN MUTATIONS AND CONGENITAL CATARACTS IN HUMANS}

Mutations in lens connexins have been associated with human disease. Missense and frame shift mutations of the $\mathrm{Cx} 46$ and $\mathrm{Cx} 50$ genes have been identified in members of families with inherited cataracts of various different phenotypes. These mutants and their associated cataract phenotypes are summarized in Table 1 (Cx46) and Table $2(\mathrm{Cx} 50)$. Other than the few exceptions noted in the tables, nearly all of the cataracts are inherited as autosomal dominant traits. The positions of these mutations in relation to the membrane topology of these connexins are shown in Figure 3.

Mutations in Cx43 have been associated with oculodentodigital dysplasia, a disease which is only rarely accompanied by cataracts. Therefore, $\mathrm{Cx} 43$ mutations are not considered in this review.

Our laboratories have been interested in determining the biochemical, cell biological and physiological abnormalities in the behaviors of these human mutants. We have expressed different cataract-associated connexin mutants using in vitro expression systems, by transfection of communication- and connexindeficient mammalian cells and by microinjection of in vitro transcribed connexin cRNAs into Xenopus oocytes. We have identified several different abnormalities (as illustrated by different examples in Table 3). In this paper, we will review some of these findings and consider their implications for understanding cataract pathogenesis. The data summarized will primarily derive from the human connexin mutant experiments performed in our laboratories.

Typically, we have performed functional and cellular screening tests in parallel. These initial studies are designed to test whether a mutant construct induces a level of intercellular conductance 
Table 1 | Human Cx46 mutants linked to cataract formation.

\begin{tabular}{|c|c|c|c|}
\hline \multirow{2}{*}{$\begin{array}{l}\text { Position and } \\
\text { alteration }\end{array}$} & \multicolumn{2}{|l|}{ Disease phenotype } & \multirow[t]{2}{*}{ Reference } \\
\hline & Cataract appearance & Other features & \\
\hline G2D & Nuclear pulverulent and posterior polar & & Yao et al. (2011) \\
\hline D3Y & Zonular pulverulent & & Addison et al. (2006) \\
\hline L11S & "Ant-egg" & & Hansen et al. (2006) \\
\hline T19M & Posterior polar & & Santhiya et al. (2010) \\
\hline V28M & Variable & & Devi et al. (2005) \\
\hline F32L & Nuclear pulverulent & & Jiang et al. (2003) \\
\hline R33L & Finely granular embryonal & & Guleria et al. (2007a) \\
\hline V44M & & & $\begin{array}{l}\text { Zhou et al. (2010), Bennett } \\
\text { and Shiels (2011) }\end{array}$ \\
\hline W45S & Nuclear & & Ma et al. (2005) \\
\hline D47N & Nuclear & & Yang et al. (2011) \\
\hline P59L & Nuclear punctate & & Bennett et al. (2004) \\
\hline N63S & Zonular pulverulent & & MacKay et al. (1999) \\
\hline R76G & Total & & Devi et al. (2005) \\
\hline $\mathrm{R} 76 \mathrm{H}$ & $\begin{array}{l}\text { Lamellar nuclear opacity with surrounding pulverulent } \\
\text { nuclear opacities; lamellar with moderate opacity of the fetal } \\
\text { nucleus and Y-shaped condensations in the anterior suture }\end{array}$ & $\begin{array}{l}\text { Dominant inheritance with } \\
\text { incomplete penetrance }\end{array}$ & $\begin{array}{l}\text { Burdon et al. (2004), Hansen } \\
\text { et al. (2009) }\end{array}$ \\
\hline T87M & "Pearl box" & & Guleria et al. (2007b) \\
\hline G143R & Coppock-like & & Zhang et al. (2012a) \\
\hline P187L & Homogeneous zonular pulverulent & & Rees et al. (2000) \\
\hline P187S & Nuclear pulverulent & & Ding et al. (2011) \\
\hline N188I & Nuclear coralliform & & Zhang et al. (2012b) \\
\hline N188T & Nuclear pulverulent & & Li et al. (2004) \\
\hline F206I & Embryonal nuclear & & Wang and Zhu (2012) \\
\hline fs380 & Zonular pulverulent & & MacKay et al. (1999) \\
\hline
\end{tabular}

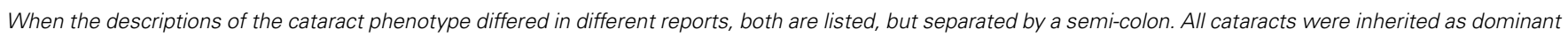
traits.

above that seen in untransfected cells or water-injected Xenopus oocytes and whether the construct leads to the formation of gap junction plaques. Plaque formation is identified as immunoreactive connexin that localizes along appositional membranes with a punctate distribution (examples are shown for wild type Cx46 and Cx50 in Figures 4 and 5).

\section{CONNEXIN MUTANTS WITH ABNORMALITIES OF CELLULAR BIOSYNTHESIS OR DEGRADATION}

The most frequently observed phenotype is a cataract-associated connexin mutant that does not induce a significant intercellular conductance and forms very few or no gap junction plaques. Examples include Cx50R23T, Cx50D47N, Cx50P88S, Cx50P88Q, and Cx46fs380 (Berthoud et al., 2003; Minogue et al., 2005; Arora et al., 2006, 2008; Thomas et al., 2008) (Table 3 and Figures 4 and 5). Among these mutants, Cx50R23T rarely forms small plaques (Thomas et al., 2008), while Cx46fs380 never forms them (Minogue et al., 2005). These differences likely reflect variations in the severity of the trafficking defects and the specific mechanisms involved.

For many of the mutants that do not form plaques, immunoreactive connexin localizes within the cytoplasm. Co-localization studies using antibodies directed against compartments of the protein biosynthetic/secretory pathway have shown that the mutant connexins are contained within the ER, ERGIC, and/or Golgi apparatus (e.g., Cx50D47N and Cx46fs380) (Minogue et al., 2005; Arora et al., 2008). The connexin within these subcellular compartments likely represents mutant protein that has been retained within the export pathway due to misfolding and/or incomplete/improper oligomerization. The interpretation that some of the mutant connexins (e.g., Cx50D47N, Cx50P88Q, Cx50P88S) are misfolded is supported by the presence of gap junction plaques at the plasma membrane after incubation of expressing cells under conditions that should promote protein folding (reduced temperatures or chemical chaperone treatment) (Berthoud et al., 2003; Arora et al., 2006, 2008).

The cytoplasmic retention of a cataract-linked mutant has been explored in detail for $\mathrm{Cx} 46 \mathrm{fs} 380$. This mutant contains a frame shift that causes a change in reading frame such that the connexin contains an abnormal C-terminal sequence. We have shown that a two amino acid motif (FF) within the abnormal polypeptide is responsible for its localization within the ERGIC and Golgi (Minogue et al., 2005). This motif has been identified as a trafficking signal in other proteins. 
Table 2 | Human Cx50 mutants linked to cataract formation.

\begin{tabular}{|c|c|c|c|}
\hline \multirow{2}{*}{$\begin{array}{l}\text { Position and } \\
\text { alteration }\end{array}$} & \multicolumn{2}{|c|}{ Disease phenotype } & \multirow[t]{2}{*}{ Reference } \\
\hline & Cataract appearance & Other features & \\
\hline R23T & Nuclear & & Willoughby et al. (2003) \\
\hline I31T & Fetal and embryonic nuclear & & Wang et al. (2009) \\
\hline T39R & Complete & Microcornea and iris hypoplasia & Sun et al. (2011) \\
\hline V44E & Total & $\begin{array}{l}\text { Microcornea and variably associated with } \\
\text { myopia }\end{array}$ & Devi and Vijayalakshmi (2006) \\
\hline W45S & Jellyfish-like & & Vanita et al. (2008b) \\
\hline G46R & Complete & Microcornea & Sun et al. (2011) \\
\hline G46V & Total & & Minogue et al. (2009) \\
\hline D47N & Nuclear pulverulent & & $\begin{array}{l}\text { Arora et al. (2008), Wang et al. } \\
\text { (2011) }\end{array}$ \\
\hline D47Y & & & Lin et al. (2008) \\
\hline E48K & "Zonular nuclear" pulverulent & & Berry et al. (1999) \\
\hline V64G & Nuclear & & Ma et al. (2005) \\
\hline S73F & $\begin{array}{l}\text { Dense and "star-shaped," various locations in } \\
\text { the nucleus or the poles }\end{array}$ & & Hansen et al. (2009) \\
\hline V79L & "Full moon" with Y-sutural opacities & & Vanita et al. (2006) \\
\hline $\mathrm{P} 880$ & $\begin{array}{l}\text { Lamellar pulverulent; balloon-like with } \\
\text { Y-sutural opacities }\end{array}$ & & $\begin{array}{l}\text { Arora et al. (2006), Vanita } \\
\text { et al. (2008a) }\end{array}$ \\
\hline P88S & Zonular pulverulent & & Shiels et al. (1998) \\
\hline P189L & $\begin{array}{l}\text { Star-shaped nuclear opacity with a whitish } \\
\text { central core }\end{array}$ & Microcornea & Hansen et al. (2007) \\
\hline R1980 & & $\begin{array}{l}\text { Microcornea and variably associated with } \\
\text { myopia }\end{array}$ & Devi and Vijayalakshmi (2006) \\
\hline R198W & & Microcornea without microphthalmia & Hu et al. (2010) \\
\hline fs203 & Total & $\begin{array}{l}\text { Recessive inheritance. Associated with } \\
\text { nystagmus and amblyopia }\end{array}$ & Ponnam et al. (2007) \\
\hline $1247 \mathrm{M}$ & Zonular pulverulent & $\begin{array}{l}\text { May be a polymorphism rather than a } \\
\text { disease-causing mutation }\end{array}$ & $\begin{array}{l}\text { Polyakov et al. (2001), Graw } \\
\text { et al. (2009) }\end{array}$ \\
\hline c776lnsG & Triangular cataract & Recessive inheritance & Schmidt et al. (2008) \\
\hline S258F & Nuclear & & Gao et al. (2010) \\
\hline S259Y & & & Hansen et al. (2009) \\
\hline S276F & Pulverulent nuclear & & Yan et al. (2008) \\
\hline L281C & Lamellar/zonular & & Kumar et al. (2011) \\
\hline
\end{tabular}

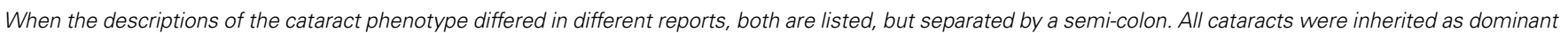
traits, except as noted.

Cx50P88S is an interesting mutant that does not form gap junction plaques when expressed by itself. It has a cytoplasmic localization, but little of the protein is localized within compartments of the biosynthetic/secretory pathway. Rather, this mutant forms cytoplasmic inclusions (1-5/cell) of $0.6-2.7 \mu \mathrm{m}$ in diameter (Berthoud et al., 2003). Similar inclusions are observed after transfection of several different cell lines. The Cx50P88S accumulations are very long lived (as compared to the turnover of the wild type protein in these expression systems) and correspond to closely apposed circular or semicircular membrane stacks that likely originate from the rough endoplasmic reticulum (Berthoud et al., 2003; Lichtenstein et al., 2009). Some of the Cx50P88S inclusions co-localize with components of the autophagic degradation pathway, and their turnover is altered by interventions that affect autophagy. Thus, the persistence of the Cx50P88S accumulations likely results from insufficient degradation capacity of constitutive autophagy (Lichtenstein et al., 2011). We have also studied another cataract-associated mutant of this connexin at the same position, Cx50P88Q. Although this mutant forms some cytoplasmic inclusions like Cx50P88S, the glutamine substitution seems to have less severe consequences than the serine substitution, since many cells expressing Cx50P88Q contain immunoreactive connexin that co-localizes with markers for the ER or Golgi (Arora et al., 2006).

Additional kinds of cellular and biochemical abnormalities may be predicted for some of the identified cataract-associated mutants. For example, phosphorylation events have been implicated in regulation of many aspects of the connexin life cycle and 


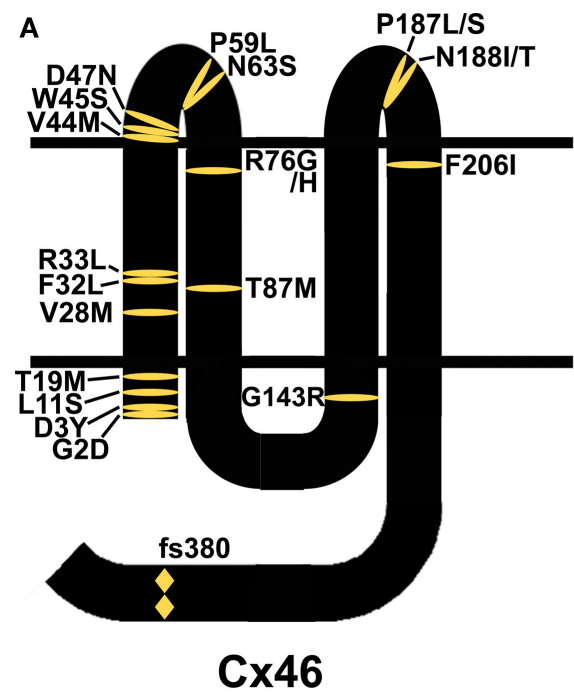

FIGURE 3 | Diagram illustrating the topology of the human lens connexins, Cx46 (A) and $\mathrm{Cx50}$ (B) and the locations of missense (I) and frame shift $(\bullet \bullet)$ mutations identified in members of families

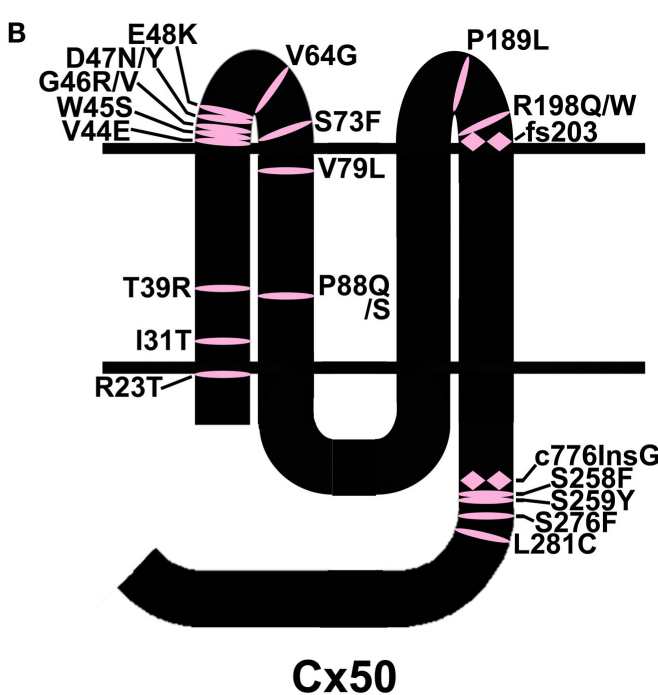

with inherited cataracts. While included in Table 2, Cx50I247M has not been included in the $\mathrm{Cx} 50$ diagram, since it may actually be a polymorphism physiology (reviewed by Solan and Lampe, 2005; Moreno and Lau, 2007). Two Cx50 mutants, Cx50S258F and Cx50S259Y, alter amino acids that are phosphorylated in the wild type protein as shown in a proteomic study of human lens membrane proteins (Wang et al., 2013); however, the cellular and physiological behaviors of these mutants have not yet been studied. In the Lop10 mouse, expression of the Cx50 mutant reduces the abundance of phosphorylated forms of $\mathrm{Cx} 46$, and the $\mathrm{Cx} 46$ alterations may contribute to the cataracts in these animals (Chang et al., 2002). The carboxyl termini of both $\mathrm{Cx} 46$ and $\mathrm{Cx} 50$ are sensitive to cleavage by calpains (Kistler and Bullivant, 1987; Lin et al., 1997; Jacobs et al., 2004). When expressed in heterologous systems, the resulting truncated Cx50 forms channels with reduced function (DeRosa et al., 2006) and sensitivity to intracellular pH (Lin et al., 1998; Xu et al., 2002). It is likely that some of the mutants within the C-terminal region of the connexin may interfere with this cleavage.

These studies allow prediction of some consequences of mutant connexin expression in the lens. All of the mutants with this general phenotype (loss of function due to a severe reduction in the number or complete absence of gap junctions) should reduce intercellular communication between lens fiber cells, regardless of their different mechanisms of retention/accumulation. In the lens, interactions of these mutants with other lens fiber cell proteins (including wild type connexins) might alter their trafficking or function as well. The mutants that are retained within the ER might cause ER stress and might lead to stimulation of the unfolded protein response. A study of the Cx50G22R and Cx50S50P mutant mice concluded that the unfolded protein response might be a contributing factor to the cataracts in these animals (Alapure et al., 2012). The stable cytoplasmic inclusions formed by some mutants (e.g., Cx50P88S) may cause light scattering and act as nucleation particles for accumulation/aggregation of other proteins.

\section{CONNEXIN MUTANTS WITH ABNORMALITIES OF CHANNEL BEHAVIOR}

The gap junction conductance between a pair of cells depends on the number of channels, their open probabilities, and their single channel conductances. The trafficking mutants discussed above are complete (or near complete) loss of function mutants, because they effectively have reduced the number of intercellular channels.

There are other mutants that form non-functional channels (e.g., Cx50W45S, Cx46D3Y, and Cx46L11S) which make abundant gap junction plaques, but have no gap junction channel activity when expressed by themselves (Tong et al., 2011, 2013) (Table 3 and Figure 3). These mutants effectively have an open probability of zero (or no unitary conductance).

Because mutant lens connexins can oligomerize with wild type Cx46 and/or Cx50 to form gap junction channels, several of the cataract-associated mutant lens connexins have been studied for their ability to alter the function of co-expressed wild type lens connexins. Some of these mutants (e.g., Cx46N63S, Cx46fs380) do not inhibit the function of either $\mathrm{Cx} 46$ or $\mathrm{Cx} 50$ (Pal et al., 2000). Other mutants (e.g., Cx50P88S, Cx50P88Q, Cx50W45S, Cx50E48K, Cx46D3Y, Cx46L11S), decrease the junctional conductance supported by their wild type counterparts (Pal et al., 1999; Arora et al., 2006; Banks et al., 2009; Tong et al., 2011, 2013). In the case of Cx50P88S, a single mutant subunit is sufficient to inhibit function of a full gap junction channel (Pal et al., 1999). Some lens connexin mutants that inhibit their homologous wild type counterparts do not act as strong dominant negative inhibitors of the other lens fiber cell connexin. For example, Cx46D3Y and Cx46L11S inhibit wild type Cx46, but they do not block wild type Cx50 (Tong et al., 2013). In addition, the function of certain lens connexin mutants such as $\mathrm{Cx} 46 \mathrm{D} 3 \mathrm{Y}$ is partially rescued by heterotypically pairing cells expressing the mutant connexin with cells expressing wild type lens connexins (Tong et al., 2013). HeLa 


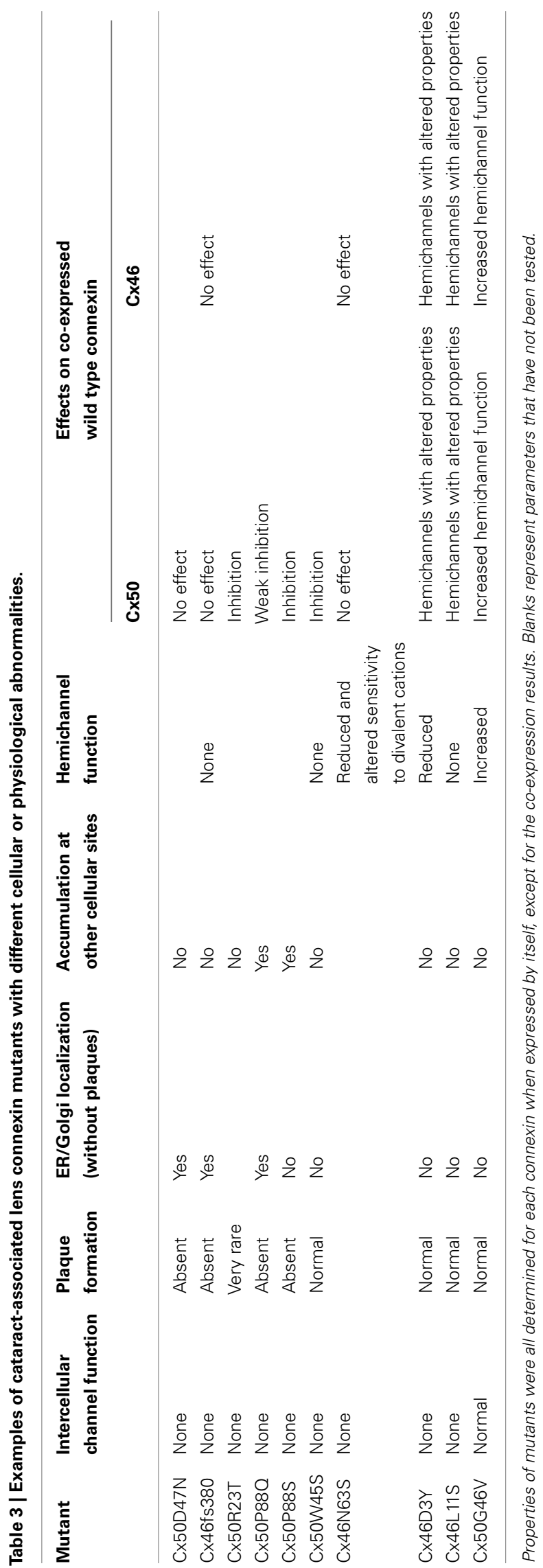

cells expressing an EGFP fusion protein of Cx46D3Y have been reported to show increased intercellular transfer of Lucifer yellow or ethidium as compared to cells expressing wild type Cx46-EGFP (Schlingmann et al., 2012).

The direct link between loss of connexin function and cataracts is an active area of research. The studies of Matthias and colleagues (reviewed in Mathias et al., 2010) have established that loss of function of either Cx46 or Cx50 (as observed in "knockout" mice) reduces coupling conductance between lens fiber cells. Reductions of intercellular communication would be anticipated to decrease the circulation of gap junction permeant molecules (including water, ions, and metabolites) between lens cells. Indeed, Gao et al. (2011) observed that reductions in gap junction channels in genetically manipulated mice resulted in a proportional decrease in the gradient of intracellular hydrostatic pressure from the center to the periphery of the lens. One hypothesis links connexin function, calcium levels and proteolysis of crystallins to cataracts based on studies of the Cx46-null mice. These animals have nuclear cataracts associated with generation of a cleaved form of $\gamma$-crystallin and significant amounts of $\mathrm{NaOH}$-insoluble $\alpha-, \beta$-, and $\gamma$-crystallins in the lens nucleus (Gong et al., 1997). Cx46null mice also have elevated levels of calcium in their lens nuclear regions (Baruch et al., 2001; Gao et al., 2004) and increased activation of calcium-dependent protease activity, likely due to the calpain3 isozyme, Lp82 (Baruch et al., 2001). Moreover, cataract formation is delayed in $\mathrm{Cx} 46$-null mice that are also deficient in the gene (Capn3) encoding this protease (Tang et al., 2007). However, the mechanism linking $\mathrm{Cx} 46$ function to cataracts in humans may be somewhat different, since CAPN3 mRNA expression has only been identified in skeletal muscle in people (Fougerousse et al., 1998).

Connexin mutants could also affect parameters such as voltage gating, sensitivity to intracellular $\mathrm{pH}$ or channel permeability that would lead to altered function, but not necessarily complete loss of function. As summarized in Table 4, Cx46 and Cx50 exhibit some differences in many of these physiological properties. Studies of mouse connexins have identified mutants (like Cx50S50P) that alter the voltage-dependent gating properties of co-expressed Cx46 or Cx50 (DeRosa et al., 2007). Interestingly, mouse Cx50S50P is also a potent inhibitor of co-expressed $\mathrm{Cx} 43$, suggesting that intercellular communication may be interrupted in lens epithelial cells where these two connexins are co-expressed (DeRosa et al., 2009). Another mouse mutant, Cx50R205G, blocks the gap junction channel function of co-expressed wild type Cx50, but only affects the gating of Cx46 channels (Xia et al., 2012).

\section{CONNEXIN FUNCTIONS BEYOND INTERCELLULAR COMMUNICATION}

In addition to forming intercellular channels, connexins can also form functional hemichannels that induce large, relatively nonselective conductances in single plasma membranes. These conductances are caused by permeation through "undocked" single connexons. This phenomenon has been best demonstrated in primary cultures of various cells and in expression systems. One of the most dramatic examples is the large permeabilities induced by expression of Cx46 in single Xenopus oocytes that can be gated by modulation of extracellular concentrations of divalent cations 

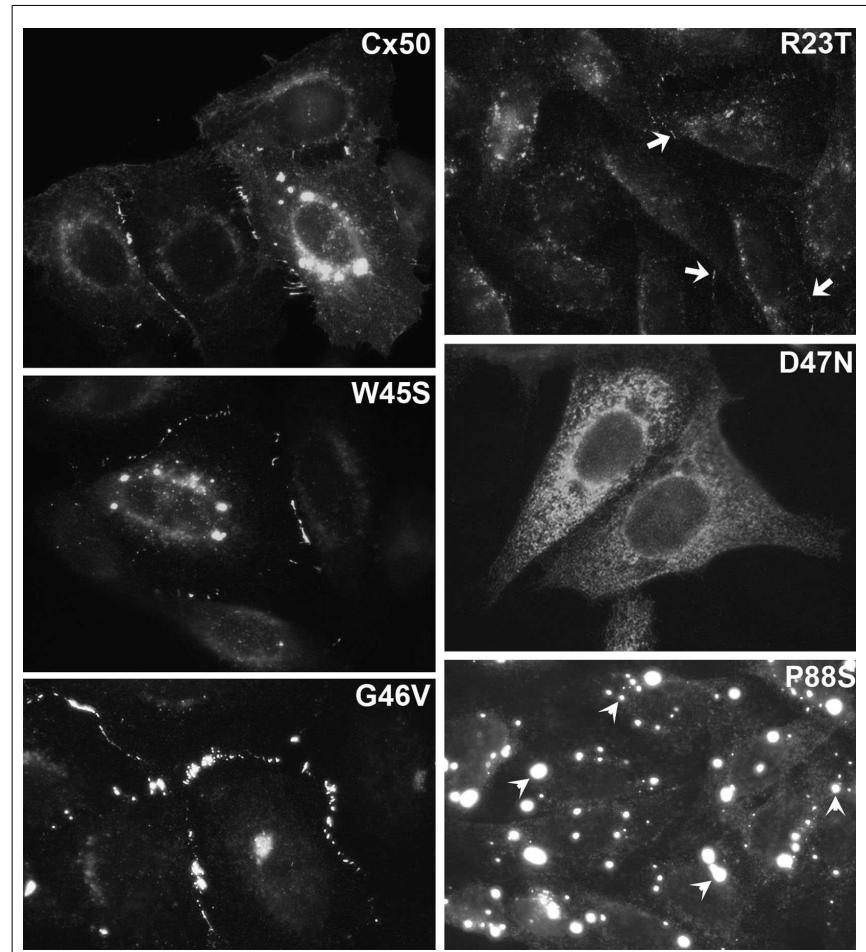

FIGURE 4 | Immunofluorescent localization of wild type Cx50 and of different cataract-associated Cx50 mutants (R23T, W45S, D47N, G46V, and P88S) after their expression by transfection of HeLa cells. Similar to wild type Cx50, W45S and G46V show abundant localization in a punctate distribution along appositional membranes corresponding to gap junction plaques. The abundance of plaques is very reduced for R23T, but small spots at appositional membranes are occasionally observed. D47N and P88S show no localization consistent with gap junction plaque formation. D47N is found in a reticular, cytoplasmic distribution. P88S localizes in intensely fluorescent cytoplasmic inclusions. Reproduced and adapted from Berthoud et al. (2003), Arora et al. (2008), Thomas et al. (2008), and Tong et al. (2011).

including calcium (Paul et al., 1991). Because Cx46 hemichannels are mechanosensitive, it has been proposed that their opening plays a physiological role during lens accommodation (Bao et al., 2004). Opening of such hemichannels has been demonstrated in isolated mouse lens fiber cells (Ebihara et al., 2010).The ability of some mutant lens connexins to form functional hemichannels has been assessed. Unlike wild type $\mathrm{Cx} 46$, many of the cataractassociated $\mathrm{Cx} 46$ mutants do not form functional hemichannels (e.g., Cx46L11S, Cx46fs380). Others exhibit a reduced ability to form them (e.g., Cx46D3Y, Cx46N63S) (Pal et al., 2000; Tong et al., 2013). Thus, entry of sodium and calcium into lens cells expressing these mutants would be impaired if $\mathrm{Cx} 46$ hemichannels serve as conduits for these ions in the normal lens.

Cataract-associated mutants may also form hemichannels with altered properties (like gating or charge selectivity) as compared with the wild type connexin. For example, Cx46N63S forms hemichannels with increased sensitivity to the extracellular concentration of magnesium ions (Ebihara et al., 2003). Cx46D3Y forms hemichannels that have altered charge selectivity and voltage gating (Tong et al., 2013).


FIGURE 5 | Immunofluorescent localization of wild type Cx46, the cataract-associated mutant Cx46fs380 (fs380), Cx46 truncated after amino acid 379 (Tr380) and Cx46fs380 with the FF motif replaced by AA (fs380AA) in transfected HeLa cells. Wild type Cx46 localizes in an intense, linear distribution along appositional membranes as expected for large gap junctions, but such staining is absent for $\mathrm{Cx} 46 \mathrm{fs} 380$ which is only found in a cytoplasmic distribution. The cytoplasmic retention must be due to the abnormal sequence in the carboxyl terminus of $\mathrm{Cx} 46 \mathrm{fs} 380$, since its removal by truncation (Tr380) restores gap junction formation. Similarly, gap junction formation is restored when the FF motif in Cx46fs380 is replaced with two alanines (fs380AA). Reproduced and adapted from Minogue et al. (2005)

A very striking alteration of hemichannel properties is exemplified by $\mathrm{Cx} 50 \mathrm{G} 46 \mathrm{~V}$, a mutant found in a patient with total cataract (Minogue et al., 2009). This mutant forms gap junction plaques and supports intercellular communication normally. However, unlike wild type $\mathrm{Cx} 50, \mathrm{Cx} 50 \mathrm{G} 46 \mathrm{~V}$ has a greatly increased ability to form functional hemichannels (Minogue et al., 2009; Tong et al., 2011). Expression of this mutant increases the proportion of apoptotic cells and causes cell death (Minogue et al., 2009) (Figure 6), suggesting that opening of the hemichannels would also cause severe cell damage in vivo. This cytotoxicity appears dominant, since co-expression of $\mathrm{Cx} 50 \mathrm{G} 46 \mathrm{~V}$ with wild type $\mathrm{Cx} 46$ or $\mathrm{Cx} 50$ also decreases cell (oocyte) viability (Tong et al., 2011). Connexin mutants with enhanced hemichannel activity may cause fiber cell death through a complex sequence of events including loss of membrane potential, disruption of transmembrane ion gradients, and entry of calcium ions, leading to activation of intracellular proteases and decreased metabolic activity.

Connexins may also be involved in functions not directly associated with their channel forming ability. Cx50 is required for normal growth of the lens. As mentioned above, mice that are null for Cx50 (but not those null for Cx46) have smaller lenses (Gong et al., 1997; White et al., 1998). The decreased lens size appears to result from reduced proliferation of lens epithelial cells, especially during the first few days of postnatal life (Sellitto et al., 2004). It has been speculated that this proliferative deficiency is due to a connexin function other than intercellular exchange of 
Table 4 | Physiological properties of wild type Cx50 and Cx46.

\begin{tabular}{|c|c|c|c|}
\hline Property & Cx50 & Cx46 & Reference \\
\hline Unitary gap junctional channel conductance & $\sim 220 \mathrm{pS}$ & $\sim 150 \mathrm{pS}$ & Srinivas et al. (1999), Hopperstad et al. (2000) \\
\hline lonic selectivity & Cations > anions & Cations > anions & Srinivas et al. (1999), Trexler et al. (2000) \\
\hline Dye permeability & DAPI, NB $>>L Y$ & $\mathrm{DAPI}>>\mathrm{LY}$ & Srinivas et al. (1999), Trexler et al. (2000), Thomas et al. (2008) \\
\hline Sensitivity to transjunctional voltage & ++ & + & $\begin{array}{l}\text { Ebihara and Steiner (1993), White et al. (1994), Srinivas et al. (1999), } \\
\text { Hopperstad et al. (2000) }\end{array}$ \\
\hline Sensitivity to intracellular $\mathrm{pH}$ & + & + & Eckert (2002), Xu et al. (2002) \\
\hline Sensitivity to activated MAPK & ++ & - & Shakespeare et al. (2009) \\
\hline Ability to form functional hemichannels & + & +++ & Paul et al. (1991), Ebihara and Steiner (1993), Beahm and Hall (2002) \\
\hline
\end{tabular}

Except for the final row, the properties refer to those of intercellular channels formed of each connexin as determined from studies in expression systems. pS, picoSiemens; DAPI, 4',6-diamidino-2-phenylindole; NB, Neurobiotin; LY, Lucifer yellow; MAPK, Mitogen-activated protein kinase.

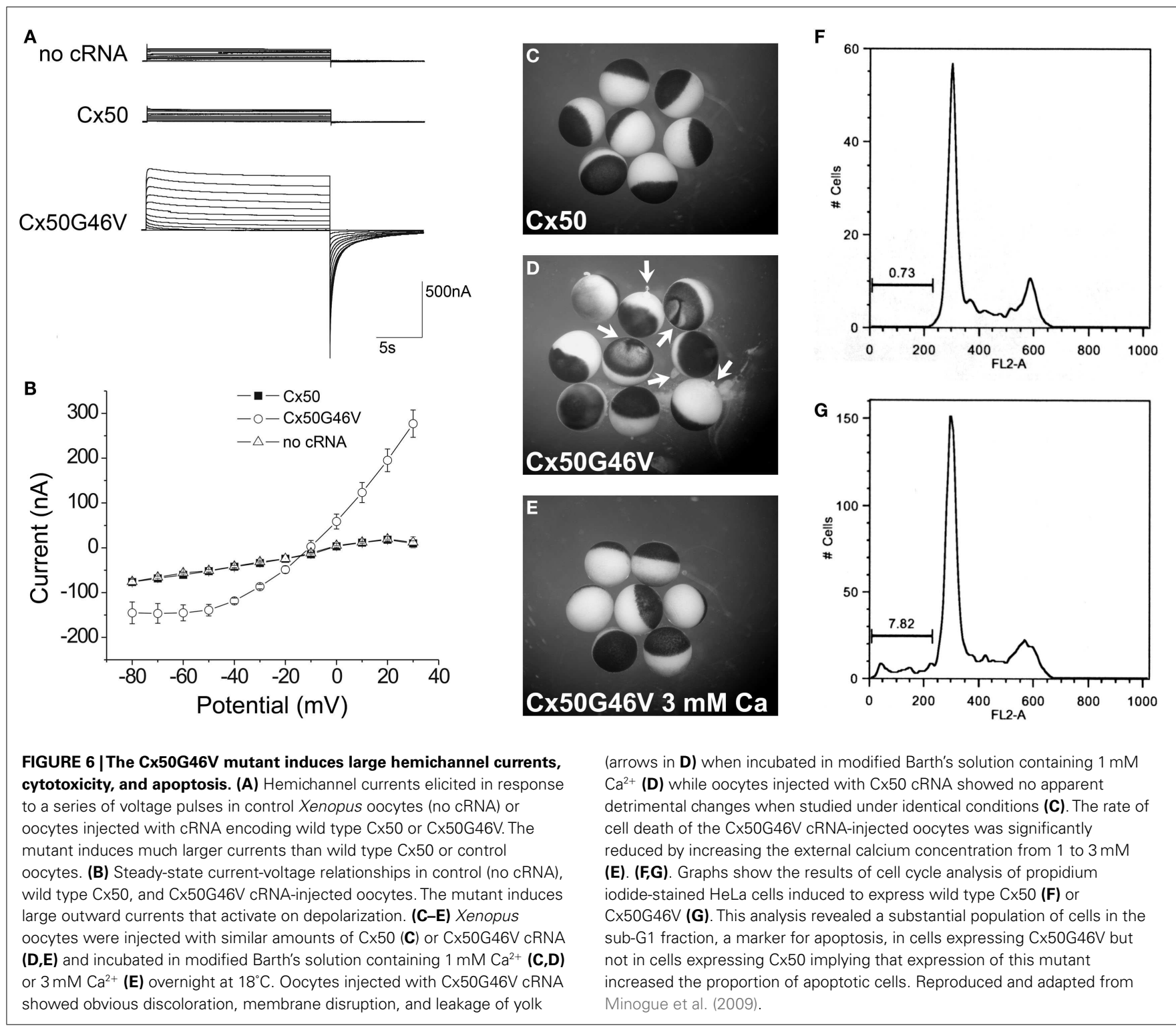


ions and small molecules, since introduction of $\mathrm{Cx} 46$ into the $\mathrm{Cx} 50$ locus does not restore normal lens growth to $\mathrm{Cx} 50$-null mice (Martinez-Wittinghan et al., 2004). Over-expression of Cx50 also leads to a decrease in lens size (Chung et al., 2007); thus, the proper level of Cx50 expression is required for normal lens development and growth.

The growth and differentiation promoting properties of Cx50 (and the roles of different portions of the molecule) have been further analyzed. Expression of the chicken Cx50 ortholog (including non-functional mutants) or a chicken $\mathrm{Cx} 46$ chimera containing the Cx50 carboxyl terminus promotes differentiation of chicken lens cells in culture (Gu et al., 2003; Banks et al., 2007). The mechanism for this "non-channel"-induced effect of Cx50 has not been clarified, but it has been suggested that it involves interactions of its carboxyl terminus with other cellular proteins to modulate intracellular signaling critical for lens cell differentiation. The major intrinsic protein, aquaporin0, is among the lens proteins that can interact with lens connexins (Yu and Jiang, 2004; Yu et al., 2005).

It is plausible that some human Cx50 mutants affect protein interactions or differentiation promoting properties involved in the normal development of the lens and other eye structures. In some of the families with inherited cataracts, affected individuals have small lenses. Moreover, in some pedigrees, the cataracts are associated with additional abnormalities including microcornea, iris hypoplasia, and myopia (see Tables 1 and 2).

\section{CONCLUSIONS AND PERSPECTIVES}

In conclusion, there are many different derangements in the cellular/biochemical behavior and function of the Cx46 and Cx50 mutants that have been linked to cataract formation.

As discussed, the most common abnormality caused by a mutation is improper trafficking and reduced gap junction plaque formation. Such mutations occur at positions throughout the connexin polypeptide, likely because deleterious substitutions of many different residues may cause misfolding (e.g., Cx50D47N). Many identified mutations involve substitutions of amino acids near the amino terminus or within the first transmembrane domain (Figure 3). Since these regions contribute to the channel pore, mutants within them (if targeted properly to the plasma membrane) would be expected to cause functional alterations (e.g., Cx46L11S). The extracellular loops are the other regions with a large number of mutations. Since the structure of these domains is critical for docking between hemichannels and for gating of hemichannels, it would be expected that mutants in this region would affect function if the mutant connexin is appropriately targeted to the plasma membrane (e.g., Cx50G46V).

Elucidating the abnormalities produced by many of these mutations will help to understand the pathogenesis of cataracts and of other diseases caused by mutations in other members of the connexin family. Indeed, reduced formation of gap junctions

\section{REFERENCES}

Abrams, C. K., and Scherer, S. S. (2012). Gap junctions in inherited human disorders of the central nervous system. Biochim. Biophys. Acta 1818, 2030-2047.

Addison, P. K., Berry, V., Holden,

K. R., Espinal, D., Rivera, B.,

leading to loss of function is also one of the most commonly observed abnormalities of disease-associated $\mathrm{Cx} 26, \mathrm{Cx} 32$, and Cx43 mutants (reviewed by Laird, 2010; Abrams and Scherer, 2012; Scott et al., 2012; Xu and Nicholson, 2012).

The cataracts associated with $\mathrm{Cx} 46$ and $\mathrm{Cx} 50$ mutants are predominantly inherited as autosomal dominant traits. This is similar to the inheritance pattern of oculodentodigital dysplasia caused by Cx43 mutants, but differs from Cx32 and most Cx26 mutants which cause disease in a recessive fashion. In some cases, the mutant connexin acts as a "dominant-negative" inhibitor of the function of the co-expressed wild type protein (like Cx50P88S) (Pal et al., 1999). But, other lens connexin mutants show little or no inhibition of the function of the wild type counterparts when studied in expression systems (Table 3). The absence of cataracts in mice that are heterozygous-null for Cx46 or Cx50 (Gong et al., 1997; White et al., 1998) implies that haplodeficiency of these connexins in mice is not sufficient to cause disease. Thus, there must be additional abnormalities conferred by the mutations that lead to lens opacities. Some of these other abnormalities such as formation of cytoplasmic inclusions or gain of hemichannel function have been considered in this review.

It is noteworthy that there are significant differences in the anatomical locations or appearances of the cataracts caused by different lens connexin mutations and among individuals within a single pedigree or in different pedigrees with the same mutation (Tables 1 and 2). Some of the phenotypic dissimilarities between different mutants likely reflect the variety of altered cellular/biochemical mechanisms, since mutants may disrupt different protein-protein interactions and affect different processes. The phenotypic differences among people with the same mutant allele imply that there are other genes that contribute to the phenotype. This conclusion is supported by the strain-dependent differences in severity of the cataracts in Cx46- and Cx50-null mice (Gong et al., 1999; Gerido et al., 2003). The differential severities of the cataracts in Cx46-null mice may partially result from differences in expression of HSP27/25 and ERp29 between strains (Hoehenwarter et al., 2008).

Finally, we can anticipate further progress in the elucidation of the mechanisms involved in cataract formation based on the characterization of additional mutants in expression systems and through the study of corresponding mutants using animal models. Eventually, these studies will contribute to the development of therapeutic approaches to prevent the formation or progression of cataracts due to connexin mutations, and perhaps those due to other genetic or non-genetic causes.

\section{ACKNOWLEDGMENTS}

This work was supported by National Institute of Health grants RO1 EY08368 (to Eric C. Beyer) and RO1 EY10589 (to Lisa Ebihara).

The unfolded protein response is activated in connexin 50 mutant mouse lenses. Exp. Eye Res. 102, 28-37.

Arora, A., Minogue, P. J., Liu, X., Addison, P. K., Russel-Eggitt, I., Webster, A. R., et al. (2008). A novel connexin50 mutation associated with congenital nuclear pulverulent cataracts. J. Med. Genet. 45, 155-160.

Arora, A., Minogue, P. J., Liu, X., Reddy, M. A., Ainsworth, J. R., Bhattacharya, S. S., et al. (2006). A novel GJA8 mutation is associated with autosomal dominant lamellar pulverulent cataract: further evidence 
for gap junction dysfunction in human cataract. J. Med. Genet. 43, e2.

Banks, E. A., Toloue, M. M., Shi, Q., Zhou, Z. J., Liu, J., Nicholson, B. J., et al. (2009). Connexin mutation that causes dominant congenital cataracts inhibits gap junctions, but not hemichannels, in a dominant negative manner. J. Cell Sci. 122, 378-388.

Banks, E. A., Yu, X. S., Shi, Q., and Jiang, J. X. (2007). Promotion of lens epithelial-fiber differentiation by the C-terminus of connexin 45.6 a role independent of gap junction communication. J. Cell Sci. 120, 3602-3612.

Bao, L., Sachs, F., and Dahl, G. (2004). Connexins are mechanosensitive. Am. J. Physiol. Cell. Physiol. 287, C1389-C1395.

Baruch, A., Greenbaum, D., Levy, E. T., Nielsen, P. A., Gilula, N. B., Kumar, N. M., et al. (2001). Defining a link between gap junction communication, proteolysis, and cataract formation. J Biol. Chem. 276, 28999-29006.

Bassnett, S., Wilmarth, P. A., and David, L. L. (2009). The membrane proteome of the mouse lens fiber cell. Mol. Vis. 15, 2448-2463.

Beahm, D. L., and Hall, J. E. (2002). Hemichannel and junctional properties of connexin 50. Biophys. J. 82, 2016-2031.

Bennett, T. M., MacKay, D. S., Knopf, H. L., and Shiels, A. (2004). A novel missense mutation in the gene for gap-junction protein $\alpha 3$ (GJA3) associated with autosomal dominant "nuclear punctate" cataracts linked to chromosome 13q. Mol. Vis. 10, 376-382.

Bennett, T. M., and Shiels, A. (2011). A recurrent missense mutation in GJA3 associated with autosomal dominant cataract linked to chromosome 13q. Mol. Vis. 17, 2255-2262.

Berry, V., MacKay, D., Khaliq, S., Francis, P. J., Hameed, A., Anwar, K., et al. (1999). Connexin 50 mutation in a family with congenital "zonular nuclear” pulverulent cataract of Pakistani origin. Hum. Genet. 105, 168-170.

Berthoud, V. M., Minogue, P. J., Guo, J., Williamson, E. K., Xu, X., Ebihara, L., et al. (2003). Loss of function and impaired degradation of a cataract-associated mutant connexin50. Eur. J. Cell Biol. 82, 209-221.

Beyer, E. C., and Berthoud, V. M. (2009). "The family of connexin genes," in Connexins: A Guide, eds A. Harris, and D. Locke (New York: Humana Press), 3-26.

Burdon, K. P., Wirth, M. G., Mackey, D. A., Russell-Eggitt, I. M., Craig, J. E., Elder, J. E., et al. (2004). A novel mutation in the Connexin 46 gene causes autosomal dominant congenital cataract with incomplete penetrance. J. Med. Genet. 41, e106.

Chang, B., Wang, X., Hawes, N. L., Ojakian, R., Davisson, M. T., Lo, W. K., et al. (2002). A Gja8 (Cx50) point mutation causes an alteration of $\alpha 3$ connexin $(\mathrm{Cx} 46)$ in semi-dominant cataracts of Lop10 mice. Hum. Mol. Genet. 11, 507-513.

Chung, J., Berthoud, V. M., Novak, L., Zoltoski, R., Heilbrunn, B., Minogue, P. J., et al. (2007). Transgenic overexpression of connexin50 induces cataracts. Exp. Eye Res. 84, 513-528.

Dahm, R., Van Marle, J., Prescott, A. R., and Quinlan, R. A. (1999). Gap junctions containing alpha8connexin (MP70) in the adult mammalian lens epithelium suggests a reevaluation of its role in the lens. Exp. Eye Res. 69, 45-56.

DeRosa, A. M., Mese, G., Li, L., Sellitto, C., Brink, P. R., Gong, X., et al. (2009). The cataract causing Cx50-S50P mutant inhibits Cx43 and intercellular communication in the lens epithelium. Exp. Cell Res. 315, 1063-1075.

DeRosa, A. M., Mui, R., Srinivas, M., and White, T. W. (2006). Functional characterization of a naturally occurring Cx50 truncation. Invest. Ophthalmol. Vis. Sci. 47, 4474-4481.

DeRosa, A. M., Xia, C. H., Gong, X., and White, T. W. (2007). The cataractinducing S50P mutation in $\mathrm{Cx} 50$ dominantly alters the channel gating of wild-type lens connexins. J. Cell Sci. 120, 4107-4116.

Devi, R. R., Reena, C., and Vijayalakshmi, P. (2005). Novel mutations in GJA3 associated with autosomal dominant congenital cataract in the Indian population. Mol. Vis. 11, 846-852.

Devi, R. R., and Vijayalakshmi, P. (2006). Novel mutations in GJA8 associated with autosomal dominant congenital cataract and microcornea. Mol. Vis. 12, 190-195.

Ding, X., Wang, B., Luo, Y., Hu, S., Zhou, G., Zhou, Z., et al. (2011). A novel mutation in the connexin 46 (GJA3) gene associated with congenital cataract in a Chinese pedigree. Mol. Vis. 17, 1343-1349.

Ebihara, L., Liu, X., and Pal, J. D. (2003). Effect of external magnesium and calcium on human connexin46 hemichannels. Biophys. J. 84 277-286.

Ebihara, L., and Steiner, E. (1993). Properties of a nonjunctional current expressed from a rat connexin 46 cDNA in Xenopus oocytes. J. Gen. Physiol. 102, 59-74.

Ebihara, L., Tong, J. J., Vertel, B., White, T. W., and Chen, T. L. (2010). Properties of connexin 46 hemichannels in dissociated lens fiber cells. Invest. Ophthalmol. Vis. Sci. 52, 882-889.

Eckert, R. (2002). pH gating of lens fibre connexins. Pflugers Arch. 443, 843-851.

Favor, J. (1983). A comparison of the dominant cataract and recessive specific-locus mutation rates induced by treatment of male mice with ethylnitrosourea. Mutat. Res. 110, 367-382.

Fougerousse, F., Durand, M., Suel, L., Pourquie, O., Delezoide, A. L. Romero, N. B., et al. (1998). Expression of genes (CAPN3, SGCA, SGCB, and TTN) involved in progressive muscular dystrophies during early human development. Genomics 48 , 145-156.

Gao, J., Sun, X., Martinez-Wittinghan, F. J., Gong, X., White, T. W., and Mathias, R. T. (2004). Connections between connexins, calcium, and cataracts in the lens. J. Gen. Physiol. 124, 289-300

Gao, J., Sun, X., Moore, L. C., White, T. W., Brink, P. R., and Mathias, R. T. (2011). Lens intracellular hydrostatic pressure is generated by the circulation of sodium and modulated by gap junction coupling. $J$. Gen. Physiol. 137, 507-520.

Gao, X., Cheng, J., Lu, C., Li, X., Li, F., Liu, C., et al. (2010). A novel mutation in the connexin 50 gene (GJA8) associated with autosomal dominant congenital nuclear cataract in a Chinese family. Curr. Eye Res. 35, 597-604.

Gao, Y., and Spray, D. C. (1998). Structural changes in lenses of mice lacking the gap junction protein connexin43. Invest. Ophthalmol. Vis. Sci. 39, 1198-1209.

Gerido, D. A., Sellitto, C., Li, L. and White, T. W. (2003). Genetic background influences cataractogenesis, but not lens growth deficiency, in Cx50-knockout mice. Invest. Ophthalmol. Vis. Sci. 44, 2669-2674.

Goel, M., Picciani, R. G., Lee, R. K., and Bhattacharya, S. K. (2010). Aqueous humor dynamics: a review. Open. Ophthalmol. J. 4 52-59.
Gong, X., Agopian, K., Kumar, N. M., and Gilula, N. B. (1999) Genetic factors influence cataract formation in $\alpha_{3}$ connexin knockout mice. Dev. Genet. 24, 27-32.

Gong, X., li, E., Klier, G., Huang, Q., Wu, Y., Lei, H., et al. (1997). Disruption of $\alpha_{3}$ connexin gene leads to proteolysis and cataractogenesis in mice. Cell 91, 833-843.

Goodenough, D. A. (1979). Lens gap junctions: a structural hypothesis for nonregulated low- resistance intercellular pathways. Invest. Ophthalmol. Vis. Sci. 18, 1104-1122.

Goodenough, D. A. (1992). The crystalline lens. A system networked by gap junctional intercellular communication. Semin. Cell Biol. 3, 49-58.

Goodenough, D. A., Dick, J., and Lyons, J. E. (1980). Lens metabolic cooperation: a study of mouse lens transport and permeability visualized with freeze-substitution autoradiography and electron microscopy. J. Cell Biol. 86, 576-589.

Graw, J., Loster, J., Soewarto, D., Fuchs, H., Meyer, B., Reis, A., et al. (2001). Characterization of a mutation in the lens-specific MP70 encoding gene of the mouse leading to a dominant cataract. Exp. Eye Res. 73, 867-876.

Graw, J., Schmidt, W., Minogue, P. J., Rodriguez, J., Tong, J. J., Klopp, N., et al. (2009). The GJA8 allele encoding CX50I247M is a rare polymorphism, not a cataract-causing mutation. Mol. Vis. 15, 1881-1885.

Gu, S., Yu, X. S., Yin, X., and Jiang, J. X. (2003). Stimulation of lens cell differentiation by gap junction protein connexin 45.6. Invest. Ophthalmol. Vis. Sci. 44, 2103-2111.

Guleria, K., Sperling, K., Singh, D., Varon, R., Singh, J. R., and Vanita, V. (2007a). A novel mutation in the connexin 46 (GJA3) gene associated with autosomal dominant congenital cataract in an Indian family. Mol. Vis. 13, 1657-1665.

Guleria, K., Vanita, V., Singh, D., and Singh, J. R. (2007b). A novel "pearl box" cataract associated with a mutation in the connexin 46 (GJA3) gene. Mol. Vis. 13, 797-803.

Hansen, L., Mikkelsen, A., Nurnberg, P., Nurnberg, G., Anjum, I., Eiberg, H., et al. (2009). Comprehensive mutational screening in a cohort of Danish families with hereditary congenital cataract. Invest. Ophthalmol. Vis. Sci 50, 3291-3303.

Hansen, L., Yao, W., Eiberg, H., Funding, M., Riise, R., Kjaer, K. 
W., et al. (2006). The congenital "ant-egg" cataract phenotype is caused by a missense mutation in connexin46. Mol. Vis. 12, 1033-1039.

Hansen, L., Yao, W., Eiberg, H., Kjaer, K. W., Baggesen, K., Hejtmancik, J. F., et al. (2007). Genetic heterogeneity in microcornea-cataract: five novel mutations in CRYAA, CRYGD, and GJA8. Invest. Ophthalmol. Vis. Sci. 48, 3937-3944.

Harris, A. L. (2001). Emerging issues of connexin channels: biophysics fills the gap. Q. Rev. Biophys. 34, 325-472.

Harris, A. L. (2007). Connexin channel permeability to cytoplasmic molecules. Prog. Biophys. Mol. Biol. 94, 120-143.

Hoehenwarter, W., Tang, Y., Ackermann, R., Pleissner, K. P., Schmid, M., Stein, R., et al. (2008). Identification of proteins that modify cataract of mouse eye lens. Proteomics 8, 5011-5024.

Hopperstad, M. G., Srinivas, M., and Spray, D. C. (2000). Properties of gap junction channels formed by $\mathrm{Cx} 46$ alone and in combination with Cx50. Biophys. J. 79, 1954-1966.

Hu, S., Wang, B., Zhou, Z., Zhou, G., Wang, J., Ma, X., et al. (2010). A novel mutation in GJA8 causing congenital cataract-microcornea syndrome in a Chinese pedigree. Mol. Vis. 16, 1585-1592.

Iovine, M. K., Gumpert, A. M., Falk, M. M., and Mendelson, T. C. (2008). Cx23, a connexin with only four extracellular-loop cysteines, forms functional gap junction channels and hemichannels. FEBS Lett. 582, 165-170.

Jacobs, M. D., Soeller, C., Sisley, A. M., Cannell, M. B., and Donaldson, P. J. (2004). Gap junction processing and redistribution revealed by quantitative optical measurements of connexin 46 epitopes in the lens. Invest. Ophthalmol. Vis. Sci. 45, 191-199.

Jiang, H., Jin, Y., Bu, L., Zhang, W., Liu, J., Cui, B., et al. (2003). A novel mutation in GJA3 (connexin46) for autosomal dominant congenital nuclear pulverulent cataract. Mol. Vis. 9, 579-583.

Jiang, J. X., and Goodenough, D. A. (1996). Heteromeric connexons in lens gap junction channels. Proc. Natl. Acad. Sci. U.S.A. 93, 1287-1291.

Kistler, J., and Bullivant, S. (1987). Protein processing in lens intercellular junctions: cleavage of MP70 to MP38. Invest.
Ophthalmol. Vis. Sci. 28, 1687-1692.

Kumar, M., Agarwal, T., Khokhar, S., Kumar, M., Kaur, P., Roy, T. S., et al. (2011). Mutation screening and genotype phenotype correlation of $\alpha$-crystallin, $\gamma$-crystallin and GJA8 gene in congenital cataract. Mol. Vis. 17, 693-707.

Laird, D. W. (2010). The gap junction proteome and its relationship to disease. Trends Cell Biol. 20, 92-101.

Li, Y., Wang, J., Dong, B., and Man, H. (2004). A novel connexin46 (GJA3) mutation in autosomal dominant congenital nuclear pulverulent cataract. Mol. Vis. 10, 668-671.

Lichtenstein, A., Gaietta, G. M., Deerinck, T. J., Crum, J., Sosinsky, G. E., Beyer, E. C., et al. (2009). The cytoplasmic accumulations of the cataract-associated mutant, Connexin50P88S, are long-lived and form in the endoplasmic reticulum. Exp. Eye Res. 88, 600-609.

Lichtenstein, A., Minogue, P. J., Beyer, E. C., and Berthoud, V. M. (2011). Autophagy: a pathway that contributes to connexin degradation. J. Cell Sci. 124, 910-920.

Lin, J. S., Eckert, R., Kistler, J., and Donaldson, P. (1998). Spatial differences in gap junction gating in the lens are a consequence of connexin cleavage. Eur. J. Cell Biol. 76, 246-250.

Lin, J. S., Fitzgerald, S., Dong, Y., Knight, C., Donaldson, P., and Kistler, J. (1997). Processing of the gap junction protein connexin50 in the ocular lens is accomplished by calpain. Eur. J. Cell Biol. 73, 141-149.

Lin, Y., Liu, N. N., Lei, C. T., Fan, Y. C., Liu, X. Q., Yang, Y., et al. (2008). [A novel GJA8 mutation in a Chinese family with autosomal dominant congenital cataract]. Zhonghua Yi. Xue. Yi. Chuan Xue. Za Zhi. 25, 59-62.

Ma, Z., Zheng, J., Yang, F., Ji, J., Li, X., Tang, X., et al. (2005). Two novel mutations of connexin genes in Chinese families with autosomal dominant congenital nuclear cataract. Br. J Ophthalmol. 89, 1535-1537.

MacKay, D., Ionides, A., Kibar, Z., Rouleau, G., Berry, V., Moore, A., et al. (1999). Connexin46 mutations in autosomal dominant congenital cataract. Am. J. Hum. Genet. 64, 1357-1364.

Martinez-Wittinghan, F. J., Sellitto, C., White, T. W., Mathias, R. T., Paul, D., and Goodenough, D. A. (2004).
Lens gap junctional coupling is modulated by connexin identity and the locus of gene expression. Invest. Ophthalmol. Vis. Sci. 45, 3629-3637.

Mathias, R. T., Kistler, J., and Donaldson, P. (2007). The lens circulation. J. Membr. Biol. 216 , 1-16.

Mathias, R. T., and Rae, J. L. (1989). "Cell to cell communication in lens," in Cell Interaction and Gap Junction, eds N. Sperelakis, and W. C. Cole (Boca Raton, FL: CRC Press, Inc.), 29-50.

Mathias, R. T., and Rae, J. L. (2004). The lens: local transport and global transparency. Exp. Eye Res 78, 689-698.

Mathias, R. T., Rae, J. L., and Baldo, G. J. (1997). Physiological properties of the normal lens. Physiol. Rev. 77, 21-50.

Mathias, R. T., White, T. W., and Gong, X. (2010). Lens gap junctions in growth, differentiation, and homeostasis. Physiol. Rev. 90, 179-206.

Miller, T. M., and Goodenough, D. A. (1986). Evidence for two physiologically distinct gap junctions expressed by the chick lens epithelial cell. J. Cell Biol. 102, 194-199.

Minogue, P. J., Liu, X., Ebihara, L., Beyer, E. C., and Berthoud, V. M. (2005). An aberrant sequence in a connexin 46 mutant underlies congenital cataracts. J. Biol. Chem. 280 40788-40795.

Minogue, P. J., Tong, J. J., Arora, A., Russell-Eggitt, I., Hunt, D. M., Moore, A. T., et al (2009). A mutant connexin50 with enhanced hemichannel function leads to cell death. Invest. Ophthalmol. Vis. Sci. 50, 5837-5845.

Moreau, K. L., and King, J. A. (2012). Protein misfolding and aggregation in cataract disease and prospects for prevention. Tr. Molec. Med. 18 273-282.

Moreno, A. P., and Lau, A. F. (2007). Gap junction channel gating modulated through protein phosphorylation. Prog. Biophys. Mol. Biol. 94 107-119.

Musil, L. S., Beyer, E. C., and Goodenough, D. A. (1990). Expression of the gap junction protein connexin 43 in embryonic chick lens: molecular cloning, ultrastructural localization, and post-translational phosphorylation. J. Membr. Biol. 116, 163-175.

Pal, J. D., Berthoud, V. M., Beyer, E. C., MacKay, D., Shiels, A. and Ebihara, L. (1999). Molecular mechanism underlying a Cx50-linked congenital cataract. Am. J. Physiol. Cell. Physiol. 276, C1443-C1446.

Pal, J. D., Liu, X., MacKay, D., Shiels, A., Berthoud, V. M., Beyer, E. C., et al. (2000). Connexin46 mutations linked to congenital cataract show loss of gap junction channel function. Am. J. Physiol. Cell. Physiol. 279, C596-C602.

Parmelee, J. T. (1986). Measurement of steady currents around the frog lens. Exp. Eye Res. 42, 433-441.

Paul, D. L., Ebihara, L., Takemoto, L. J., Swenson, K. I., and Goodenough, D. A. (1991). Connexin46, a novel lens gap junction protein, induces voltage- gated currents in nonjunctional plasma membrane of Xenopus oocytes. J. Cell Biol. 115, 1077-1089.

Piatigorsky, J. (1980). Intracellular ions, protein metabolism, and cataract formation. Curr. Top. Eye Res. 3, $1-39$

Polyakov, A. V., Shagina, I. A., Khlebnikova, O. V., and Evgrafov, O. V. (2001). Mutation in the connexin 50 gene (GJA8) in a Russian family with zonular pulverulent cataract. Clin. Genet. 60, 476-478.

Ponnam, S. P., Ramesha, K., Tejwani, S., Ramamurthy, B., and Kannabiran, C. (2007). Mutation of the gap junction protein alpha 8 (GJA8) gene causes autosomal recessive cataract. J. Med. Genet. 44, e85.

Puk, O., Loster, J., Dalke, C., Soewarto, D., Fuchs, H., Budde, B., et al. (2008). Mutation in a novel connexinlike gene (Gjfl) in the mouse affects early lens development and causes a variable small-eye phenotype. Invest. Ophthalmol. Vis. Sci. 49, 1525-1532.

Rae, J. L., and Kuszak, J. R. (1983). The electrical coupling of epithelium and fibers in the frog lens. Exp. Eye Res. $36,317$.

Reaume, A. G., Desousa, P. A., Kulkarni, S., Langille, B. L., Zhu, D. G., Davies, T. C., et al. (1995). Cardiac malformation in neonatal mice lacking connexin43. Science 267, 1831-1834.

Rees, M. I., Watts, P., Fenton, I., Clarke, A., Snell, R. G., Owen, M. J., et al. (2000). Further evidence of autosomal dominant congenital zonular pulverulent cataracts linked to 13q11 (CZP3) and a novel mutation in connexin 46 (GJA3). Hum. Genet. 106, 206-209. 
Resnikoff, S., Pascolini, D., Etya'ale, D., Kocur, I., Pararajasegaram, R., Pokharel, G. P., et al. (2004). Global data on visual impairment in the year 2002. Bull. World Health Organ. 82, 844-851.

Robinson, K. R., and Patterson, J. W. (1982). Localization of steady currents in the lens. Curr. Eye Res. 2, 843-847.

Rong, P., Wang, X., Niesman, I., Wu, Y., Benedetti, L. E., Dunia, I., et al. (2002). Disruption of Gja8 ( $\alpha 8$ connexin) in mice leads to microphthalmia associated with retardation of lens growth and lens fiber maturation. Development 129, 167-174.

Saez, J. C., Berthoud, V. M., Branes, M. C., Martinez, A. D., and Beyer, E. C. (2003). Plasma membrane channels formed by connexins: their regulation and functions. Physiol. Rev. 83, 1359-1400.

Santhiya, S. T., Kumar, G. S., Sudhakar, P., Gupta, N., Klopp, N., Illig, T., et al. (2010). Molecular analysis of cataract families in India: new mutations in the CRYBB2 and GJA3 genes and rare polymorphisms. Mol. Vis. 16, 1837-1847.

Schlingmann, B., Schadzek, P., Busko, S., Heisterkamp, A., and Ngezahayo, A. (2012). Cataract-associated D3Y mutation of human connexin46 (hCx46) increases the dye coupling of gap junction channels and suppresses the voltage sensitivity of hemichannels. J. Bioenerg. Biomembr. 44, 607-614.

Schmidt, W., Klopp, N., Illig, T., and Graw, J. (2008). A novel GJA8 mutation causing a recessive triangular cataract. Mol. Vis. 14, 851-856.

Scott, C. A., Tattersall, D., O’Toole, E. A., and Kelsell, D. P. (2012). Connexins in epidermal homeostasis and skin disease. Biochim. Biophys. Acta 1818, 1952-1961.

Sellitto, C., Li, L., and White, T. W. (2004). Connexin50 is essential for normal postnatal lens cell proliferation. Invest. Ophthalmol. Vis. Sci. 45, 3196-3202.

Shakespeare, T. I., Sellitto, C., Li, L., Rubinos, C., Gong, X., Srinivas, M., et al. (2009). Interaction between Connexin50 and mitogen-activated protein kinase signaling in lens homeostasis. Mol. Biol. Cell 20, 2582-2592.

Shiels, A., MacKay, D., Ionides, A., Berry, V., Moore, A., and Bhattacharya, S. (1998). A missense mutation in the human connexin50 gene (GJA8) underlies autosomal dominant "zonular pulverulent" cataract, on chromosome 1q. Am. J. Hum. Genet. 62, 526-532.

Solan, J. L., and Lampe, P. D. (2005). Connexin phosphorylation as a regulatory event linked to gap junction channel assembly. Biochim. Biophys. Acta 1711, 154-163.

Sonntag, S., Sohl, G., Dobrowolski, R., Zhang, J., Theis, M., Winterhager, E., et al. (2009). Mouse lens connexin23 (Gjel) does not form functional gap junction channels but causes enhanced ATP release from HeLa cells. Eur. J. Cell Biol. 88, 65-77.

Srinivas, M., Costa, M., Gao, Y., Fort, A., Fishman, G. I., and Spray, D. C. (1999). Voltage dependence of macroscopic and unitary currents of gap junction channels formed by mouse connexin50 expressed in rat neuroblastoma cells. J. Physiol. (Lond.) 517(Pt 3), 673-689.

Sun, W., Xiao, X., Li, S., Guo, X., and Zhang, Q. (2011). Mutational screening of six genes in Chinese patients with congenital cataract and microcornea. Mol. Vis. 17, 1508-1513.

Steele, E. C. J., Lyon, M. F., Favor, J., Guillot, P. V., Boyd, Y., and Church, R. L. (1998). A mutation in the connexin 50 (Cx50) gene is a candidate for the No2 mouse cataract. Curr. Eye Res. 17, 883-889.

Tang, Y., Liu, X., Zoltoski, R. K., Novak, L. A., Herrera, R. A., Richard, I., et al. (2007). Age-related cataracts in a3Cx46-knockout mice are dependent on a calpain 3 isoform. Invest. Ophthalmol. Vis. Sci 48, 2685-2694.

TenBroek, E. M., Johnson, R., and Louis, C. F. (1994). Cell-to-cell communication in a differentiating ovine lens culture system. Invest. Ophthalmol. Vis. Sci. 35, 215-228.

Thomas, B. C., Minogue, P. J., Valiunas, V., Kanaporis, G., Brink, P. R., Berthoud, V. M., et al. (2008). Cataracts are caused by alterations of a critical $\mathrm{N}$-terminal positive charge in connexin50. Invest. Ophthalmol. Vis. Sci. 49, 2549-2556.

Tong, J. J., Minogue, P. J., Guo, W., Chen, T. L., Beyer, E. C., Berthoud, V. M., et al. (2011). Different consequences of cataractassociated mutations at adjacent positions in the first extracellular boundary of connexin50. Am. J. Physiol. Cell. Physiol. 300, C1055-C1064.

Tong, J. J., Sohn, B. C., Lam, A., Walters, D. E., Vertel, B. M., and Ebihara, L. (2013). Properties of two cataract associated mutations located in the $\mathrm{N}$-terminus of Connexin 46. Am. J. Physiol Cell Physiol. doi:10.1152/apjcell.00344. 2012

Trexler, E. B., Bukauskas, F. F., Kronengold, J., Bargiello, T. A., and Verselis, V. K. (2000). The first extracellular loop domain is a major determinant of charge selectivity in connexin46 channels. Biophys. J. 79, 3036-3051.

Vanita, V., Hennies, H. C., Singh, D., Nurnberg, P., Sperling, K., and Singh, J. R. (2006). A novel mutation in GJA8 associated with autosomal dominant congenital cataract in a family of Indian origin. Mol. Vis. 12 , 1217-1222.

Vanita, V., Singh, J. R., Singh, D., Varon, R., and Sperling, K. (2008a). A mutation in GJA8 (p.P88Q) is associated with "balloon-like" cataract with Y-sutural opacities in a family of Indian origin. Mol. Vis. 14 1171-1175.

Vanita, V., Singh, J. R., Singh, D., Varon, R., and Sperling, K. (2008b). A novel mutation in GJA8 associated with jellyfish-like cataract in a family of Indian origin. Mol. Vis. 14, 323-326.

Wang, K., Wang, B., Wang, J., Zhou, S., Yun, B., Suo, P., et al. (2009). A novel GJA8 mutation (p.I31T) causing autosomal dominant congenital cataract in a Chinese family. Mol. Vis. 15, 2813-2820.

Wang, K. J., and Zhu, S. Q. (2012). A novel p.F206I mutation in Cx46 associated with autosomal dominant congenital cataract. Mol. Vis. 18, 968-973.

Wang, L., Luo, Y., Wen, W., Zhang, S., and Lu, Y. (2011). Another evidence for a D47N mutation in GJA8 associated with autosomal dominant congenital cataract. Mol. Vis. 17, 2380-2385.

Wang, Z., Han, J., David, L. L., and Schey, K. L. (2013). Proteomics and phosphoproteomics analysis of human lens fiber cell membranes. Invest. Ophthalmol. Vis. Sci. 54 1135-1143

White, T. W., Bruzzone, R., Goodenough, D. A., and Paul, D. L. (1992). Mouse Cx50, a functional member of the connexin family of gap junction proteins, is the lens fiber protein MP70. Mol. Biol. Cell 3, 711-720.

White, T. W., Bruzzone, R., Wolfram, S., Paul, D. L., and Goodenough, D. A. (1994). Selective interactions among the multiple connexin proteins expressed in the vertegrate lens: the second extracellular domain is a determinant of compatibility between connexins. J. Cell Biol. 125, 879-892.

White, T. W., Goodenough, D. A., and Paul, D. L. (1998). Targeted ablation of connexin50 in mice results in microphthalmia and zonlular pulverulent cataracts. J. Cell Biol. 143, 815-825.

White, T. W., Sellitto, C., Paul, D. L., and Goodenough, D. A. (2001). Prenatal lens development in connexin 43 and connexin50 double knockout mice. Invest. Ophthalmol. Vis. Sci. 42, 2916-2923.

Willoughby, C. E., Arab, S., Gandhi, R., Zeinali, S., Arab, S., Luk, D., et al. (2003). A novel GJA8 mutation in an Iranian family with progressive autosomal dominant congenital nuclear cataract. J. Med. Genet. 40, e124.

Xia, C. H., Chang, B., DeRosa, A. M., Cheng, C., White, T. W., and Gong, X. (2012). Cataracts and microphthalmia caused by a gja8 mutation in extracellular loop 2. PLOS ONE. 7:e52894. doi:10.1371/journal.pone. 0052894

Xia, C. H., Cheng, C., Huang, Q., Cheung, D., Li, L., Dunia, I., et al. (2006). Absence of $\alpha 3$ (Cx46) and $\alpha 8(\mathrm{Cx} 50)$ connexins leads to cataracts by affecting lens inner fiber cells. Exp. Eye Res. 83, 688-696.

Xu, J., and Nicholson, B. J. (2012). The role of connexins in ear and skin physiology - functional insights from disease-associated mutations. Biochim. Biophys. Acta 1828, 167-178.

Xu, X., Berthoud, V. M., Beyer, E. C., and Ebihara, L. (2002). Functional role of the carboxyl terminal domain of human connexin 50 in gap junctional channels. J. Membr. Biol. 186, 101-112.

Yan, M., Xiong, C., Ye, S. Q., Chen, Y., Ke, M., Zheng, F., et al. (2008). A novel connexin 50 (GJA8) mutation in a Chinese family with a dominant congenital pulverulent nuclear cataract. Mol. Vis. 14 418-424.

Yang, G., Xing, B., Liu, G., Lu, X., Jia, X., $\mathrm{Lu}, \mathrm{X}$., et al. (2011). A novel mutation in the GJA3 (connexin46) gene is associated with autosomal dominant congenital nuclear cataract 
in a Chinese family. Mol. Vis. 17, 1070-1073.

Yao, K., Wang, W., Zhu, Y., Jin, C., Shentu, X., Jiang, J., et al. (2011). A novel GJA3 mutation associated with congenital nuclear pulverulent and posterior polar cataract in a Chinese family. Hum. Mutat. 32, 1367-1370.

Yu, X. S., and Jiang, J. X. (2004). Interaction of major intrinsic protein (aquaporin-0) with fiber connexins in lens development. J. Cell Sci. 117, 871-880.

Yu, X. S., Yin, X., Lafer, E. M., and Jiang, J. X. (2005). Developmental regulation of the direct interaction between the intracellular loop of connexin 45.6 and the $\mathrm{C}$ terminus of major intrinsic protein (aquaporin-0). J. Biol. Chem. 280, 22081-22090.

Zhang, L., Qu, X., Su, S., Guan, L., and Liu, P. (2012a). A novel mutation in GJA3 associated with congenital Coppock-like cataract in a large Chinese family. Mol. Vis. 18, 2114-2118.

Zhang, X., Wang, L., Wang, J., Dong, B., and Li, Y. (2012b). Coralliform cataract caused by a novel connexin46 (GJA3) mutation in a Chinese family. Mol. Vis. 18, 203-210.

Zhou, Z., Hu, S., Wang, B., Zhou, N., Zhou, S., Ma, X., et al.
(2010). Mutation analysis of congenital cataract in a Chinese family identified a novel missense mutation in the connexin 46 gene (GJA3). Mol. Vis. 16, 713-719.

Conflict of Interest Statement: The authors declare that the research was conducted in the absence of any commercial or financial relationships that could be construed as a potential conflict of interest.

Received: 15 February 2013; accepted: 26 March 2013; published online: 15 April 2013.
Citation: Beyer EC, Ebihara $L$ and Berthoud VM (2013) Connexin mutants and cataracts. Front. Pharmacol. 4:43. doi: 10.3389/fphar.2013.00043

This article was submitted to Frontiers in Pharmacology of Ion Channels and Channelopathies, a specialty of Frontiers in Pharmacology.

Copyright () 2013 Beyer, Ebihara and Berthoud. This is an open-access article distributed under the terms of the Creative Commons Attribution License, which permits use, distribution and reproduction in other forums, provided the original authors and source are credited and subject to any copyright notices concerning any third-party graphics etc. 